"Microcredit provides thousands of people, most often women, with the means to pull themselves out of

poverty. It has the power to improve the lives of individuals and empower them to be responsible for their own economic success." 


\section{THE RIGHT PARADIGM FOR PUNO A Microfinance Case Study}

KERRY BRENNAN

AMONG THE MANY PROGRAM MODELS EMPLOYED TO SPUR ECONOMIC DEVELOPMENT, MICROFINANCE HAS RISEN TO THE FOREFRONT BECAUSE OF ITS PROMISE OF A" WINWIN" SITUATION FOR DONORS AND CLIENTS. MICROFINANCE INSTITUTIONS PROVIDE FINANCIAL SERVICES SUCH AS SMALL BUSINESS LOANS TO POOR BORROWERS WHO WOULD OTHERWISE LACK CREDIT ACCESS. BECAUSE THESE INSTITUTIONS BOAST REPAYMENT RATES AS GOOD AS OR BETTER THAN TRADITIONAL INSTITUTIONS, THE PROMISE OF SUSTAINABILITY OR EVEN PROFITABILITY EXISTS. AND YET, WHILE THIS PROMISE ATTRACTS ATTENTION TO MICROFINANCE INSTITUTIONS AND THEIR DEVELOPMENT GOALS, IT MAY PLACE TOO MUCH PRESSURE ON SOME PROGRAMS. TWO BROAD PARADIGMS APPLY TO THE GOALS OF MICROFINANCE: THE INSTITUTIONIST AND THE WELFARIST. USING THE EXAMPLE OF A SMALL MICROFINANCE PROGRAM IN PERU, THIS PAPER EXPLORES SOME OF THE ISSUES SURROUNDING THE USE OF EACH PARADIGM IN EVALUATING INDIVIDUAL MICROFINANCE PROGRAMS. 
Muhammad Yunus, an economist from Bangladesh, bought the 2006 Nobel Peace Prize for 27 dollars. Of course, Yunus did not buy the Nobel Prize in a shady deal in Sweden. Rather, he won it because of his commitment to microcredit, a commitment that started with a loan of just 27 dollars in 1976 . The concept of microfinance has been the darling of development programs for several years, but it has gained special exposure recently. Before Yunus was awarded the Nobel Prize in 2006, the United Nations declared 2005 the Year of Microcredit. This recent attention is well-founded: microcredit provides thousands of people, most often women, with the means to pull themselves out of poverty. It has the power to improve the lives of individuals and empower them to be responsible for their own economic success. The very virtue of microcredit is its simple concept-providing loans to poor individuals who would otherwise have no chance at obtaining credit to improve their situations. This seeming simplicity unfortunately means that it is all too easy to create well-intentioned microfinance programs that are not self-sustainable or do

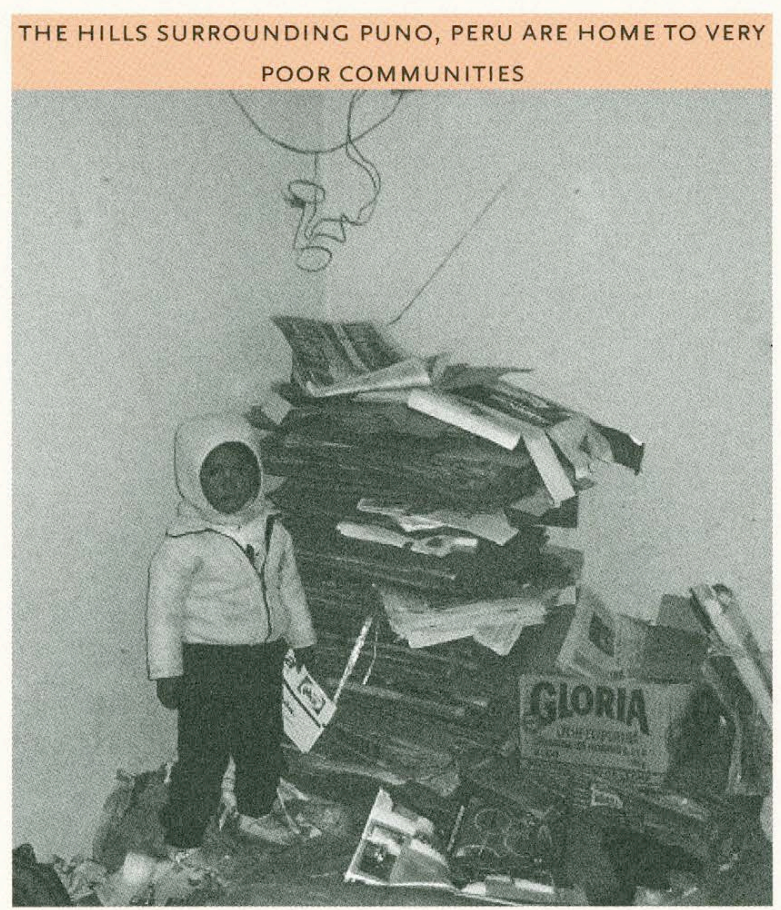

not serve their clients as efficiently as possible. As microfinance becomes more popular, it has garnered attention from mutual funds and formal finance institutions, pushing the need for sustainability. While microfinance appears to provide a "win-win" situation, there is something of a split between those who stress the welfare benefits of microfinance and those who stress institutional sustainability. Both goals cannot always be achieved simultaneously. This paper presents as a case study of a small microlending program in the city of Puno, Peru. The responses garnered from a survey administered to microlending clients shed light on the impact of the program and the amount of work it has left to do. Rather than suggesting that either a welfarist or institutionist view is always the correct paradigm, it shows the need for the proper application of both perspectives when evaluating microfinance programs.

Microfinance has gained much popularity because of its broad appeal as a "win-win" option for the problem of poverty alleviation. "Spurred by an accord reached at the Microfinance Summit in 1997 to reach roo million of the world's poorest households with credit, there is arguably more widespread support for microfinance than any other single tool for fighting world poverty." Clients of microfinance institutions (MFIs) benefit from access to money for investment or consumption, and, depending on the lending arrangement, eventual sustainability or even profitability for MFIs appears within reach. "Advocates who lean left highlight the 'bottom-up' aspects, attention to community, focus on women, and, most importantly, the aim to help the underserved." ii On the other side of the spectrum, "those who lean right highlight the prospect of alleviating poverty while providing incentives to work, the nongovernmental leadership, the use of mechanisms disciplined by market forces, and the general suspicion of ongoing subsidization." iii With these myriad possibilities, it is no wonder that microfinance has garnered widespread adulation and MFIs have sprung up all over the developed and developing world. Providing credit access to poor borrowers epitomizes the charitable ideal of "teaching a man to fish." And, given the significance of gender inequalities worldwide and 
their detrimental effects on development, the fact that microfinance is more likely to produce a fisherwoman makes it even more attractive. The economic empowerment of women can have important consequences for human development. Women are more likely to spend income on food, clothing, and education for their children, a tendency that translates into dynamic and self-reinforcing improvements in the human capital of their community.

Alleviating poverty is not a new goal; the innovation that draws praise for the most recent incarnations of microfinance programs is less about improving the lives of the poor than it is about creating institutions that will eventually become sustainable engines of poverty alleviation, without further subsidization. This innovation presents a very attractive alternative to what some may see as a constant outflow of poverty aid dollars that produces intangible results. To begin with, it is worth distinguishing between two forms of sustainability. The first hurdle of sustainability is operational sustainability. "This refers to the ability of institutions to generate enough revenue to cover operating costs-but not necessarily the full cost of capital."iv Once operational sustainability has been achieved, the next goal becomes financial sustainability, which "is defined by whether or not the institution requires subsidized inputs in order to operate." $\vee$ Some people insist that financial sustainability is the only option for MFIs, arguing, "Only financially sound, professional organizations have a chance to compete effectively, access commercial loans, become licensed to collect deposits, and grow to reach significant scale and impact." vi This "best practices" conception of microlending stands in contrast to the reality of most programs. "While subsidy rates will surely fall as more programs gain age and scale, even many older, larger programs are far from being able to make ends meet with their own revenues." vii It appears that the goals of sustainability and eventual profitability are less attainable than was once thought. "What began as a grass-roots 'movement' motivated largely by a development paradigm is evolving into a global industry informed increasingly by a commercial/financial paradigm."viii This can be separated into two broad categories: the institutionist and the welfarist. Institutionists place greatest importance on the institutional viability of programs as a means to their continued survival and financial sustainability. Welfarists take a different view of the concept of sustainability. In their conception, donors function as social investors who expect a social or intrinsic return on their investment as opposed to a financial one. "Microfinance social investors take this notion to the limit, generally earning zero financial returns and relying totally upon intrinsic returns." ix While institutionists are likely to emphasize the importance of the commerical/financial paradigm, welfarists would fit better into the social development paradigm.

Certainly the "win-win" possibilities of microfinance are largely responsible for its current position as the darling of the development world. Despite these possibilities, microfinance programs still fall under the umbrella of antipoverty programs, which have never been held to standards of financial sustainability or profit. The dual nature of microfinance means that there is much debate about its position in the world of development and finance. The way it is treated in the literature reflects this as well. One study, pub-

"Spurred by an accord reached at the Microfinance Summit in 1997 ... there is arguably more widespread support for microfinance than any other single tool for fighting world poverty." 
lished in 2004, calculated the frequency with which articles about microfinance appear in various journals. The journals containing the most articles were development focused: Small Enterprise Development, The Journal of Microfinance, World Development, The Journal of Developmental Entrepreneurship, and The Journal of International Development. ${ }^{\mathrm{x}}$ Business and financial publications contain a minimum of articles, perhaps illustrating that "the challenge today is a more systemic one: finding ways to better integrate a full range of microfinance services with mainstream financial systems and markets." $x$ Recent coverage of microfinance programs has highlighted the social entrepreneurship aspect of microfinance and its newfound buzz factor within the financial community. One 2006 Financial Times article describes a decision by Citibank to invest in microfinance: "Ajay Banga, who heads Citigroup's consumer businesses outside the US, said such initiatives would help make microfinance 'sustainable as a business.' 'Hopefully, it will inspire similar moves in other countries." xii A more recent article spotlights the Acumen Fund, a non-profit venture mutual fund that "takes a business-like approach to improving the lives of the poor,"xiii and has received grants from Google.org and the Rockefeller and Cisco Foundations. Helping the poor has always required funding from donors, and attracting the attention of mutual funds and social investors ought to be seen as a positive development. This paradigm shift, however, has required MFIs to reevaluate their mission and the place that sustainability has within it.

In evaulating sustainability, there are two main concerns. First, for donors attracted by the possibility of helping to create a self-supporting anti-poverty program, it presents the need for a reevaluation of their donation goals. If they decide that sustainability and profitability outweigh other social benefits, it is possible they will withdraw funding from non-financially sustainable projects. Morduch writes, "It is not clear why the starting point for so many is the belief that, as a matter of course, funding will be pulled away from programs, even those able to demonstrate sustained social effectiveness."xiv If the goal is poverty alleviation,

\section{"[The] Acumen Fund... 'takes a business-like approach to improving the lives of the poor.",}

even microfinance programs that do not achieve full sustainability can be beneficial and worth supporting. Secondly, the idea of long-running subsidies raises legitimate concerns about the efficiency of microlending programs. Subsidized loan programs of the past fell victim to inefficiencies and low levels of repayment. Morduch argues, "If constraints are kept hard and performance criteria are made clear, managers must cope with failures, and efficiency can be maintained, even in nonprofit programs." $\mathrm{xy}$ As with other nonprofit organizations, incentives and constraints other than financial profit can be used to maintain efficient operations in subsidized programs.

The means of achieving sustainability are thought to be found in larger scale programs or increased interest rates. While microlending programs boast repayment rates as high as or higher than commercial lending operations, repayment cannot be equated with sustainability. With the small size of most microloans, increasing interest rates appears the most viable option. This choice, however, may prevent poorer borrowers from gaining access to funds. It also runs the risk of introducing a moral hazard into operations, as borrowers seeking funds for riskier (but higher return) investments are the ones more likely to borrow even in the face of high interest rates. Even if these problems can be surmounted, interest rates may face constraints due to the entrance of new lenders into the microfinance market and increasing competition among MFIs. This competition can favor subsidized institutions because it allows them to maintain lower interest rates and attract more desirable clients. $x$ i The question of sustainability continues to affect how MFIs evaluate day to day decisions 


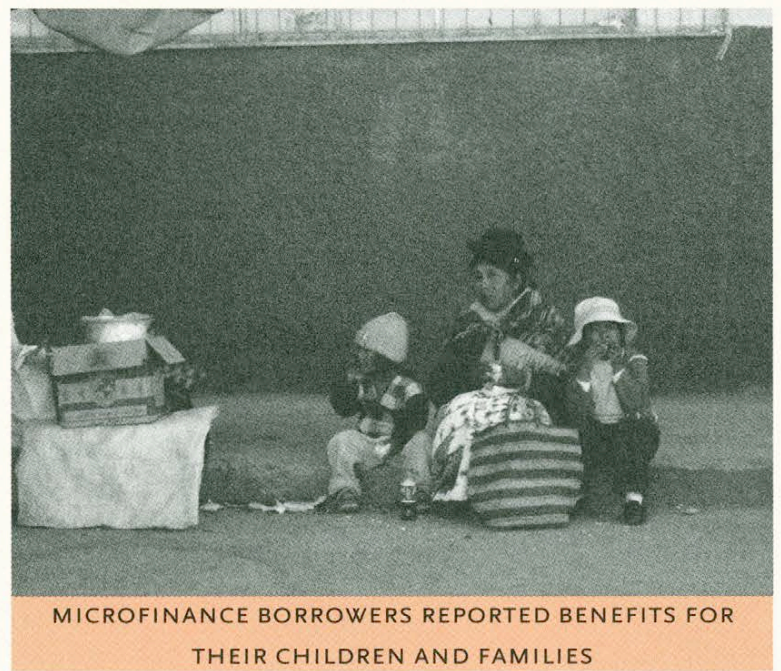

regarding their business operations.

Unfortunately, measuring a MFI's financial position is much easier than measuring its social impact. A number of studies have attempted to measure the effect of microloans on the financial and social position of borrowers and the ability of loans to spur job creation and economic growth. xvii Measuring the social impact of loans is very difficult for a number of reasons. First, it is difficult to pin down how a study should define "social impact." The myriad benefits that are attributed to successful microlending operations-the empowerment of women and increased household consumption to name a couple - mean that social impact tends to be broadly defined. More than that, it is difficult to distinguish whether impacts are the result of microfinance programs or other changes in the lives of borrowers. One recent development in the testing of microfinance programs relies on randomized field trials that attempt to control specific features of microfinance programs in order to isolate what causes their social and economic impacts. With the development of these research techniques, more reliable data is becoming available. Despite the increasing importance of these field experiments, much research gauges social effect based on surveys of microfinance clients. xviii
The results of a survey I administered to clients of the small microlending program of the Centro de Apoyo al Desarrollo de la Mujer y el Niño (CEADMUN, Center for Support of the Development of Women and Children) provide a case study to reveal the institutionist and welfarist tensions that face all microfinance institutions struggling to reach levels of sustainability, be it operational or financial. CEADMUN is located in the city of Puno, Peru, a city in the Andean altiplano on the shores of Lake Titicaca. A popular tourist destination with a population of around 100,000, Puno also is home to very poor communities living mostly in the hills surrounding the city. The work of CEADMUN combines women's empowerment, education, and capacity-building with a small microfinance program. As the name of the organization promises, their primary goals center upon increasing the economic and social development opportunities of women and children. Profitability for their microlending program is seen as a possible future goal but not the main objective. Funding for CEADMUN's operations comes from donations from a Swiss priest living in a nearby city and from partnerships with other non-profit organizations, as well as the initial capital that was put up by the organization's four founding employees.

Loans are generally made to solidarity groups that arise from neighborhood women's groups, though some loans to individuals are made as well. Borrowers use their loan funds to support small businesses that include the sale of handicrafts, knitted goods, clothing (usually used), animals, fish, cosmetic products, and kerosene, and the operation of small stores and restaurants. The geographic distribution of solidarity groups affects the businesses in which they participate, as well as their levels of prosperity. For example, Los Balseritos, the solidarity group of Los Uros, sells handicrafts to tourists and fish to puneños and is known for their timeliness in repaying loans. Los Uros are a chain of man-made floating reed islands where people have been living for centuries. They are the main attraction drawing tourists to Puno. This group's position stands in contrast to other groups from the neighborhoods in the muddy hills surrounding the city center, which are not nec- 
essarily guaranteed the captive customer audience of tourists visiting the floating islands. Clients are also required to make savings deposits that are available for withdrawal twice during the year: once at the beginning of the school year to assist in the purchase of the materials necessary for school attendance and again at Christmas time when extra consumption needs are expected. As an intern in the office during the months of January and February of 2006 , I wrote and administered a survey to gauge the impact of the microlending program on the clients. The survey consisted of a series of questions regarding the personal, business, and social situation of each borrower. In particular, I was interested in determining the effects that loans had on the financial position of the women, but also the effect they had on their self-esteem.

The survey sample included 3I surveys. All of the clients surveyed were women with the exception of one man, the husband of a CEADMUN borrower. Interestingly, the majority of the respondents (27 of 3I) had previously borrowed from a microlending institution other than CEADMUN. The most common institution named was the popular ProMujer organization, which has offices in Peru, Nicaragua, Argentina, Mexico, and Bolivia. From a demographic perspective, it was a varied group. All those surveyed had at least one child, with an average of almost three children each, and many were living in homes that included members of their extended family. The education levels of those surveyed also varied greatly, ranging from three women who had no formal instruction to seven women with partial or complete university training. The range of education levels was apparent in the administration of the survey. The challenge of collecting reliable data from participants was occasionally hampered by a lack of mathematical experience on the part of the borrower, as in the case of estimating the effects of a loan on her business. Additionally, it is important to mention that these surveys asked questions from the perspective of comparing the borrowers' lives with the loan to their lives without the loan. This means that environmental factors over time are not fully accounted for in the survey design. These considera- tions make the interpretation of the survey results problematic from a statistical point of view, but do not necessarily preclude all of their ability to assist in an understanding of the program's impact on the lives of borrowers.

Overall, the results of the survey demonstrate that loans from CEADMUN were judged by borrowers to exert a positive impact on their lives. Loans from CEADMUN did not provide start-up capital for any of the women, who all had their businesses previous to their loans. They did, however, allow women to increase the size of their businesses or the consumption of their families. Twenty-seven women responded "yes" to the question of whether their business had improved after the loan. The improvement was generally attributed to an ability to buy more merchandise or materials. Pressed further for details of the increases, however, clients were often not able to state exactly how much

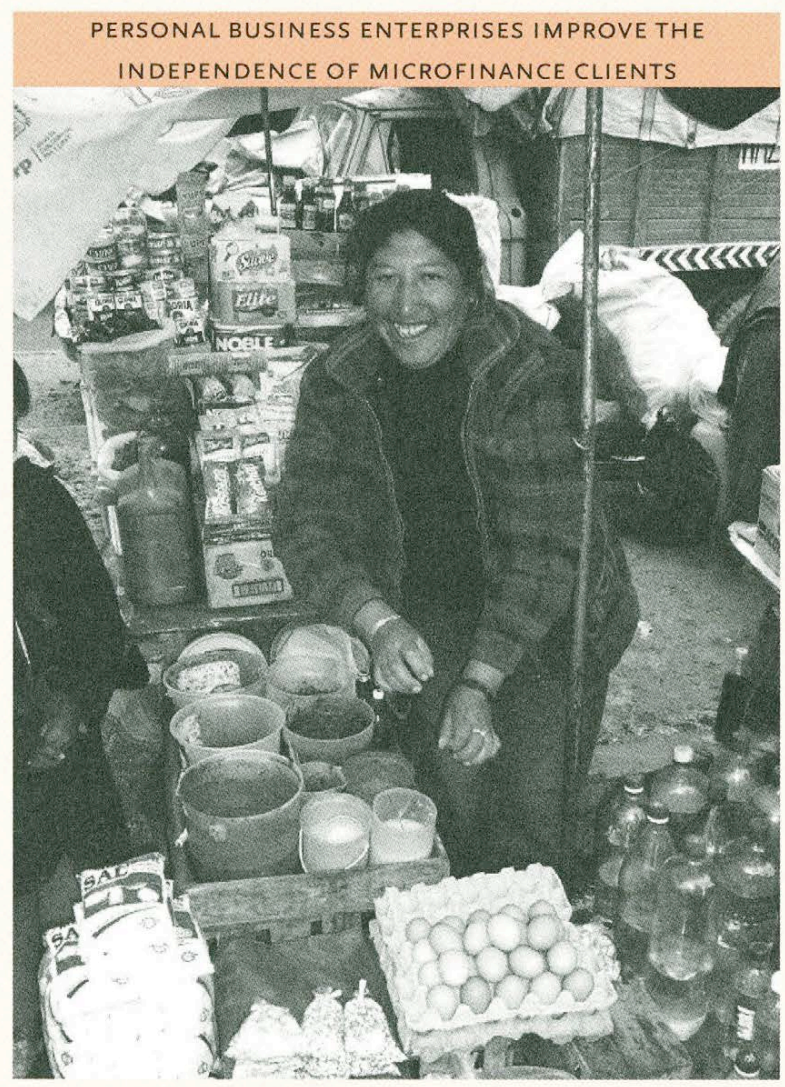


they had spent per week or month on merchandise prior to receiving the loan.

Fourteen respondents also indicated that they re-invested their earnings into their business, and nearly all borrowers stated that they would borrow greater amounts and expand their businesses if they were allowed to. This response with regard to borrowing more funds, however, contradicts the responses to other questions on the survey; it was made by even those women who had previously answered that their businesses had not improved or that they were experiencing a decreased demand for their products. This suggests that either borrowers are too pessimistic in their judgment of their business or that they are too optimistic in their hopes for new loans.

Benefits regarding the support of borrowers' children were also widely reported. Fourteen respondents explicitly stated children, family, and education in their responses to the question of where they spent their increased earnings. Other responses included expenditures on housing, food, and clothing which can all contribute to the ability of a child to succeed in school. Two respondents in particular as serted that without their loans, they would not have been able to send their children to school. Apart from the material well-being reported by respondents, the series of questions related to the borrowers' self-esteem and general personal satisfaction were enlightening. All respondents replied in a positive manner to the question, "How do you feel, as a person, upon carrying out your business?" Some individual responses show that the loans are achieving their goal of female empowerment. One 35-year-old woman expressed the independence that results from her loan: "If I want to, I go out." xix Echoing that freedom of decision making are the responses: "What I want to buy, I can,"xx and "Now I don't have to depend on anyone." Another client, trained in economics at the university level, said that her loan makes her feel optimistic and allows her more stability than other jobs. It is clear from these responses that running a business of their own, supported by access to credit, has improved the independence and free- dom of opportunity for many clients of CEADMUN.

As a way to gauge the economic and political awareness of CEADMUN's clients, I included the survey question, "How do you see the economic situation of Peru?" Responses tended towards laments about the lack of jobs and opportunities to earn money. Perhaps the most interesting responses to this question touched on the issue of competition. While some literature on microfinance addresses the issue of competition between MFIs, the issue of increased competition between borrowers is also an issue. In the case of Puno, many women sell handicrafts and sweaters to the many tourists who pass through the city. With loans, they are able to purchase more merchandise to sell, but there has not necessarily been an accompanying increase in tourists to the city. The street near the port from which tours of the floating islands depart is lined with women selling their colorful wares. The idea of a merchandise shortage would not cross the mind of any observer. It is not surprising, then, that several women mentioned that competition had contributed to a downturn in their business. This problem should correct itself with borrowers borrowing less if they are unable to sell increased levels of merchandise, but it is worth considering whether the loans themselves are creating problems by introducing too much supply into certain markets. Furthermore, the type of business that many CEADMUN borrowers have-selling items on the street-is not likely to lead to the capital accumulation that would allow them a real way out of poverty. The organization would do well to consider expanding their business education to encourage more dynamic enterprises.

A preliminary consideration of the case of CEADMUN in Puno illustrates the tensions between the institutionist and welfarist positions. An institutionist would likely criticize the small program's prospects for reaching the levels of operational sustainability and financial sustainability that will ensure its survival and continued ability to reach those in need. A welfarist, on the other hand, would emphasize the positive impact that the loans have had on borrowers' lives over the need for financial sustainability. The microfinance 
literature provides support for both a development and a financial paradigm, but which provides the best fit for this example? In the case of CEADMUN, several institutional factors combine with the results of the monitoring survey to support a positive evaluation from a developmental, welfarist evaluation of the program. As a small institution focusing on a holistic approach to the question of economic and social development, CEADMUN was never created with the intention of becoming a profitable microlending institution. The resources it has available in terms of technical expertise and loanable funds do not provide a practical environment for the goal of financial sustainability. In a similar vein, the loans that it is able to make are not to borrowers who are likely to achieve the kind of financial gains from their investments that could create profitable future lending possibilities. Investors interested in financial gain would take one look at their small office and the businesses the loan program supports and be certain that they were not interested. This, of course, is if they find themselves in Puno at all. Yet while CEADMUN's loans do not appear to be producing truly great financial gains for either clients or the center, they do demonstrate a self-reported positive impact on borrowers' lives. The impact on women's self concept and independence is particularly promising, as is the increase in household income earmarked for spending on children. If the microfinance program is seen as a way of stretching charity funds that would otherwise be spent on other development initiatives such as empowerment training or the provision of food and clothing, it can remain an important part of the organization's arsenal of development activities without ever reaching sustainability. When MFIs are able to leverage their resources in a way that makes the "win-win" possibility of microfinance a real possibility, they should do just that. But the popularity and success of such programs should not make it the sole paradigm under which microfinance is considered. A "win-win" scenario might be ideal, but even a "win-break even" scenario is a useful tool in the fight against poverty.

\section{ENDNOTES}

i. McIntosh and Wydick (271-298)

ii. Murdoch 1999 (I570) iii. Murdoch 1999 (1570) iv. Murdoch I999 (I588)

v. Murdoch 1999 (1588)

vi. Littlefield and Rosenberg

vii. Murdoch 2000

viii. Brau and Woller (I-26)

ix. Brau and Woller (I-26)

$\mathrm{x}$. Brau and Woller (I-26)

xi. Littlefield and Rosenberg

xii. Wighton

xiii. Foster

xiv. Foster

xv. Murdoch 2000

xvi. For a more in depth discussion of the issue of competition among MFIs, see McIntosh and Wydick "Competition and Microfinance" 2002

xvii. Brau and Woller provide a comprehensive description of several of these studies.

xviii. Duflo, E.R. Glennerster, \&M. Kremer. 2006. Using randomization in development economics research: a toolkit. Handbook of Development Economics.

xix. Original Spanish response from January 2006 interview: "Si yo quiero, salgo."

xx. Original Spanish response from January 2006 interview:

"Lo que yo quiero comprar, yo puedo."

xxi. Original Spanish response from January 2006 interview: "Ya no tengo que depender de nadie."

\section{REFERENCES}

Brau, James C. and Gary M. Woller. 2004. "Microfinance: A Comprehensive Review of the Existing Literature." Journal of Entrepreneurial Finance and Business Ventures. 9(I).

Foster, Lauren. 2007. "One fund stretches charity dollar." Financial Times, January 26.

Littlefield, Elizabeth and Richard Rosenberg, 2004. "Microfinance and the Poor." Finance and Development, June.

McIntosh, Craig and Bruce Wydick. 2005. "Competition and Microfinance," Journal of Development Economics, $78(2)$, December:

Murdoch, Jonathan. I999. "The Microfinance Promise." Journal of Economic Literature. 37(4), December.

Murdoch, Jonathan. 2000. "The Microfinance Schism." World Development. 28(4).

Wighton, David. 2006. "COMPANIES THE AMERICAS: Citigroup in microfinance programme." Financial Times, September 22 